\title{
A new species of Putzeysia Sulliotti, 1889 (Gastropoda Eucy- clidae) from the lonian Sea (Italy)
}

\author{
Agatino Reitano ${ }^{*}$ \& Danilo Scuderi ${ }^{2}$ \\ ${ }^{1}$ Museo di Storia Naturale di Comiso, Via degli Studi 9, 97013 Comiso, Italy; external collaborator of Museo della \\ Fauna del Dipartimento di Scienze Veterinarie dell’Università di Messina, Italy; e-mail: tinohawk@yahoo.it \\ ${ }^{2}$ Via Mauro de Mauro 15B, Piano Tavola, 95032 Belpasso, Catania, Italy; e-mail: stiliger38@gmail.com \\ *Corresponding author
}

\begin{abstract}
A new species of the genus Putzeysia Sulliotti, 1889 (Gastropoda Eucyclidae) is here described from the infralittoral rocky bottoms of Catania: P. rickyi n. sp. Empty shells have been found in a shell grit collected at the base of a prehistoric lava escarpment at low depth. The new species is placed in Putzeysia on the basis of morphological characters. In the Mediterranean Sea this genus is represented by a single species, P. wiseri (Calcara, 1842), also known for other Lusitanic and North-eastern European localities. A comparison with close similar congeneric species allowed to distinguish differences on both shell and environment of the new species.
\end{abstract}

KEY WORDS Gastropoda; Eucyclidae; Putzeysia; Ionian Sea; Sicily.

Received 22.10.2021; accepted 12.11.2021; published online 20.12.2021

\section{INTRODUCTION}

The genus Putzeysia Sulliotti, 1889, whose systematic position was discussed in Guidastri et al. (1984), belongs to Eucyclidae (Marshall, 2020) and includes four extant species: the most known bathyal $P$. wiseri, from Mediterranean Sea, Lusitanian and Northern Atlantic regions, and three other only recently described species, i.e. P. cillisi Segers, Swinnen et De Prins, 2009, from Madeira, $P$. franziskae Engl et Rolán, 2009 and $P$. juttae Engl et Rolán, 2009 both from Canary islands. Only one fossil species is currently known of this genus, $P$. clathrata (Aradas, 1847), type species of the genus (Sulliotti, 1889), but it is considered as synonym of the extant Mediterranean species (Marshall, 2021), erroneously in our opinion.

During ARA divings along the shoreline of Catania, at the depth of 38 meters, three shells of the genus Putzeysia have been found inside few kilos of shell grit collected in August 2021 by the first Author at the base of a prehistoric lava escarpment.
This finding has been considered surprising because of the low bathymetry, unusual for the Mediterranean species. Further studies on this material revealed significant morphological differences with the Mediterranean congener. Compared to the other extra-Mediterranean species, which show analogies concerning the bathymetric distribution, the shell of the newly found species revealed greater difference than in P. wiseri. Under these circumstances, the Sicilian species is here described as new.

\section{MATERIAL AND METHODS}

About $3 \mathrm{~kg}$ of shell grit were manually collected and placed inside a sack-shaped net which retains a fraction greater than $1 \mathrm{~mm}$ inside. Sediments were regularly washed with fresh water added with sodium hypochlorite in low concentrations, dried and sieved. Then, shell specimens were picked out from the $>1 / 2 / 3 \mathrm{~mm}$ fractions. Specimens were examined and measured under a stereomicroscope, 
and photographed with a Canon EOS 700D camera with a Tamron $60 \mathrm{~mm}$ lens, in multifocal shots. Photographs were processed with the combineZM software. Subsequently, images were converted to black and white and the balance of lights and shadows was modified to obtain more contrasted images which highlight the morphological characteristics of the shells. The specimens were also examined uncoated under a LMU Tescan Vega Scanning Electron Microscope in Low Vacuum modality, to investigate its micromorphology.

ACRONYMS. NC: Andrea Nappo malacological collection (Cagliari, Italy). MSNC: Museo di Storia Naturale di Comiso, Italy. CR: Agatino Reitano malacological collection (Tremestieri Etneo, Catania, Italy). CS: Danilo Scuderi malacological collection (Piano Tavola, Belpasso, Italy).

\section{RESULTS}

\section{Systematics}

Classis GASTROPODA Cuvier, 1795

Subclassis VETIGASTROPODA Salvini-Plawen, 1980

Ordo SEGUENZIIDA Haszprunar, 1986

Superfamilia SEGUENZIOIDEA Verrill, 1884

Familia EUCYCLIDAE Koken, 1896

Genus Putzeysia Sulliotti, 1889

Type species: Trochus clathratus Aradas, 1847

Putzeysia rickyi n. $\mathrm{sp}$.

https://zoobank.org:act:2ADA5CF8-5CD0-4F6D8022-B0C4B15798D5

Material examined. Holotype, Catania, Sicily, Italy, 23.VIII.2021, legit A. Reitano, shell grit at the base of a lava escarpment 38 meters depth, MSCN 4853. Paratype A, same data of the holotype (CS). Paratype B, same data of the holotype (CR).

DESCRIPTION OF HOLOTYPE. Shell turbinoid (height $4 \mathrm{~mm}$, width $3.2 \mathrm{~mm}$ ) thin, globose, with 5.5 spiral whorls, the last one rounded representing more than $45 \%$ of the total height. Protoconch tilted up, with about 1.25 whorls, a diameter of $410 \mu \mathrm{m}$ and a nucleus of about $210 \mu \mathrm{m}$. Under strong magnification the protoconch appears partially scarificated, but delicate papillae are visible on its sides. The opening has the edge slightly folded outwards. From the first whorl of the teleoconch numerous, delicate, irregular and discontinuous spiral lines start: diverging in the abapical area, downwards below. Teleoconch whorls with axial ribs: 20 on the first whorl, 27 on the penultimate, about 38 on the last whorl, which are prosocline and narrower than the interspaces. At the beginning of the penultimate turn a sub-sutural cord appears; at about halfway of the same whorl the basal cord turns away from the suture making it appear canaliculated and deeper. On the last whorl, in an apertural view, 5 spiral cords are present (the subsutural one smaller and close to the next one), which become 8 in the last half of the whorl, close to aperture. They cross over the axial ribs, forming nodules at the intersections. Below the end of the spire, 5 nodulous cords run down to the base, crossed by thin axial ribs forming smooth nodules. Aperture rounded, peristome sharp, slightly serrated due to the end of the spiral cords. There are not internal nodules. Umbilicus narrow. The columella is straight, with a faint fold and an everted border. Colour milky white. Periostracum not present (Figs. 5-7).

VARIABILITY. Paratype A (height $3.6 \mathrm{~mm}$, width $3.2 \mathrm{~mm}$ ) represents specimen not full grown. It has 23 axial ribs on the penultimate whorl and generally presents the same features of the holotype, but related to its size (Figs. 2, 8-10).

The paratype B (height $5.4 \mathrm{~mm}$, width $3.9 \mathrm{~mm}$ ) has a more elongated shape (Fig. 3). It is a gerontic and freak specimen. Theleoconch whorls with axial ribs: 25 on the first whorl, 30 on the penultimate, not definable on the last whorl because the shell was damaged. In fact, at about 1.5 whorls, there is a repaired break, starting from which only two spiral cords appear. At the beginning of the penultimate whorl, a very thin cord appears, which at the end of the penultimate whorl is divided into two. At the same point another cord appears at the base, close to the suture. On the last whorl, in an apertural view, 7 cords are present, two of which are more prominent. These prominent cords give to the shell a pagoda-like shape. They cross over the thin cords, forming very weak nodules at the crossing points. Therefore, on the whole shell, except the last whorl, the axial sculpture is prevalent, giving it a different architecture than the holotype. There are only 3 nodulous cords down to the base, crossed over by thin axial ribs forming very smooth nodules. The area close to umbilicus is smooth. Aperture rounded, peristome slightly thick. There are not internal nodules. Umbilicus narrowed. Nine spiral cords are present close to the end of the last whorl (Fig. 4).

Etymology. The species is named in memory of Riccardo (Ricky) Mangano (2018-2021), grandson of the first Author. 


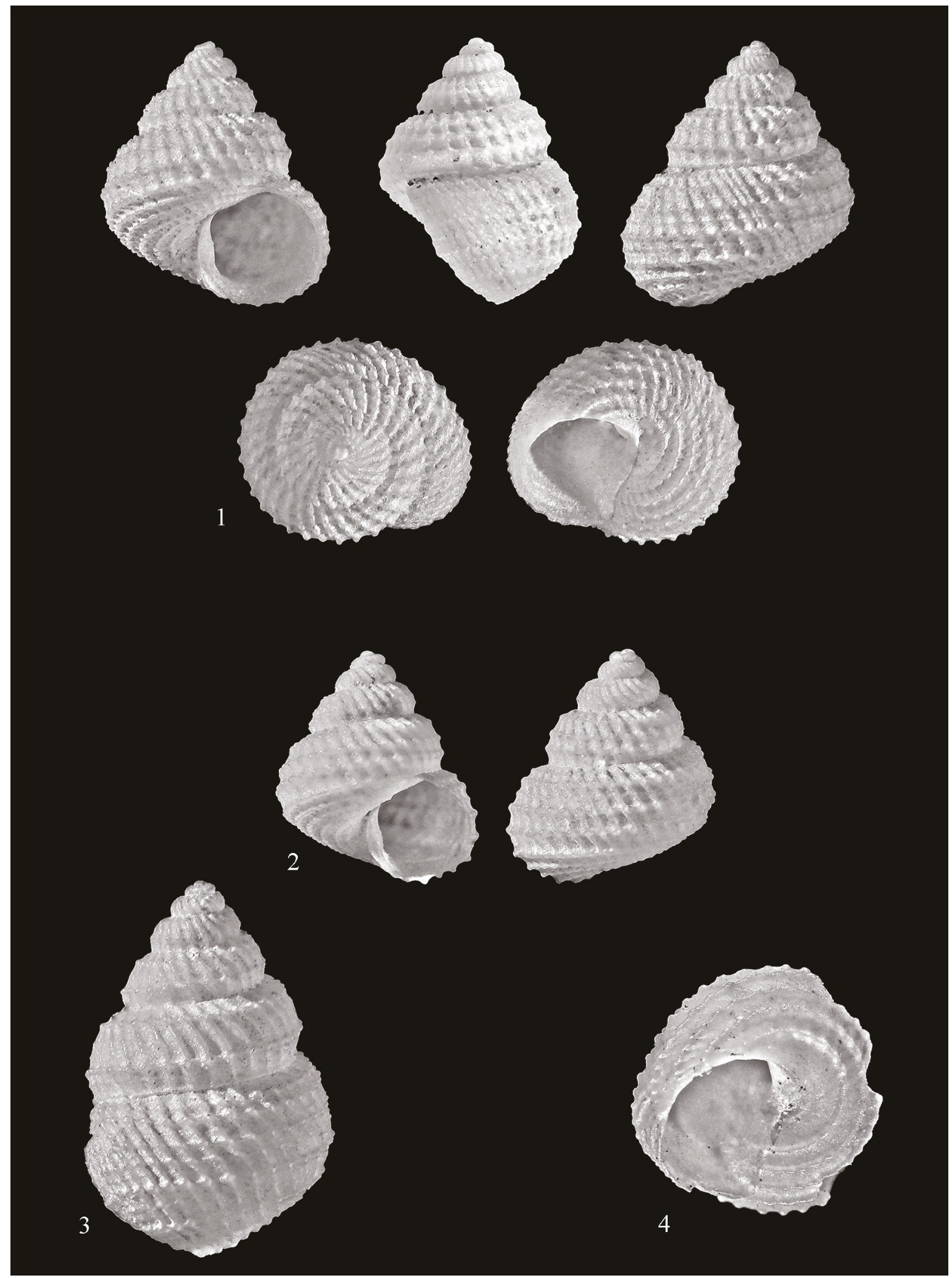

Figures 1-4. Putzeysia rickyi n. sp. Fig. 1: holotype, from different views, height $4 \mathrm{~mm}$, width $3.2 \mathrm{~mm}$ (MSCN 4853). Fig. 2: paratype A: height $3.6 \mathrm{~mm}$, width $3.2 \mathrm{~mm}(\mathrm{CS})$. Figs. 3, 4: paratype B: height $5.4 \mathrm{~mm}$, width $3.9 \mathrm{~mm}(\mathrm{CR})$. 
Biology And Distribution. Putzeysia rickyi n. sp. come from a thanatocenosis represented by typical species of the photophilic algae (AP) biocenosis (sensu Pérès \& Picard, 1964): Tricolia pullus (Linnaeus, 1758), Jujubinus spp., Clanculus spp.; coastal detritic (DC) biocenosis: Tellina donacina Linnaeus, 1758, Turritella turbona Monterosato, 1877; and muddy detritic bottom (DE) biocenosis: Plagiocardium papillosum (Poli, 1795), Bolma rugosa (Linnaeus, 1767), Calyptraea chinensis (Linnaeus, 1758).

The shell grit was found at the base of an escarpment generated by lavas of "Ognina" dated between $15,000 \mathrm{ka}$ and $3930 \pm 60 \mathrm{a}$ (Branca et al., 2011). The presence in the site of the findings of only recent lavas substrate since at least $15,000 \mathrm{ka}$ and the absence of detrital accumulation from deeper depths, furthermore corroborated by the shell composition above reported and typically derived from coastal extant byocenosis, exclude the possibility that materials of the new species may be considered as derived from more ancient contexts, as fossil or pseudo-fossil specimens. Therefore it can be assumed that Putzeysia rickyi n. sp. lives on rocky photophilic bottoms. The species is known only from type locality.

Remarks. Putzeysia rickyi n. sp. differs from $P$. wiseri for the different shell shape, more rounded in the latter (Figs. 11-13). Moreover, the new species has an higher number of axial prosocline ribs on the first teleoconch whorl (20-25 V.S. 1518 in $P$. wiseri) and a lower number of spiral cords on the penultimate whorl (3 V.S. 4-6 in P. wiseri). On the last whorl, in apertural view, in the new species there are 5-7 spiral cords V.S. 6-7 in $P$. wiseri, which could become double. Therefore $P$. wiseri shows generally many more nodules at the crossing points. Furthermore, in contrast to $P$. wiseri, $P$. rickyi $\mathrm{n}$. sp. has a thinner shell and does not show any traces of notches inside the aperture. Protoconchs of species of Putzeysia are all almost swollen, with only very small papillae on the surface. In P. rickyi is of the same type, with only light differences: the nucleus is slightly bigger and papillae are limited to the lateral sides, but this latter could be due to the abrasion of the few specimens found.

Anyway, the new species cannot be compared with the congeneric $P$. wiseri for its different environment preferences, as well as for its very different bathymetric distribution. In fact, the latter species lives on coral or muddy bottoms between 150 and $3000 \mathrm{~m}$ depth, but it is more frequent in association with deep-sea corals in the range between 500 and $2000 \mathrm{~m}$, where it could be considered a cold-water species relict living in association with deep water corals, as Lophelia, Madrepora, Desmophyllym, Caryophillia, and others, in Mediterranean, Lusitanian and Notheastern Atlantic (Jeffreys, 1880, 1883; Glibert, 1962; Ghisotti et al., 1971; Di Geronimo et al., 1973; Guidastri et al., 1984; Janssen , 1989; Smriglio et al., 1989; Poppe et al., 1991; Giannuzzi-Savelli et al., 1994; Palazzi et al., 1996; Ardovini et al., 1999; Ratmeyer et al., 2004; Portalatina, 2008; Mastrototaro et al., 2010; Taviani et al., 2011; Rosso et al., 2010; Scaperrotta et al., 2010; Cossignani et al., 2011; Sysoev, 2014; Negri et al., 2016; Taviani et al., 2017; Nasto et al., 2018). Only Seguenza (1876b) has reported $P$. wiseri in lower waters, about 150-200 meters, from the coralligenous bottoms of the Messina strait: notwithstanding the peculiar environment present due to the notorious currents situation in the strait, this latter data should be confirmed by more recent findings. Calcara (1842, 1845) previously described $P$. wiseri on the basis of specimens collected among fossiliferous sediments of Messina and, few years later the first description, Philippi (1844) described two fossil species from the same geographic area: Trochus crispulus and Trochus gemmulatus. Aradas (1847) reported both these latter species from the outcrops of Gravitelli, near Messina. The description and drawing given by Philippi suggest that $T$. crispulus is a synonym of $P$. wiseri, but leave the taxon $T$. gemmulatus to uncertain interpretation (Guidastri et al., 1984; Coan et al., 2017).

Among the Quaternary sediments with deep sea faunal assemblages of central and southern Italy $P$. wiseri is widespread (Seguenza G., 1876a; Greco et al., 1974; Di Geronimo, 1979; Di Geronimo \& Li Gioi, 1980; Guidastri et al., 1984; Di Geronimo \& Bellagamba, 1985; Micali et al., 1985; Rindone et al., 1989; Bonfitto et al.,1994; Barrier et al., 1996; Vazzana, 1996; Di Geronimo \& La Perna, 1997a; Di Geronimo et al., 1997b; Bertolaso et al., 2000; Di Geronimo et al., 2005).

Two species from Canary islands were previously reported as $P$. wiseri (Engl, 2005), but subsequently they were described as new (Engl \& Rolàn, 2009): P. franziskae Engl et Rolán, 2009 and P. juttae Engl et Rolán, 2009. They show more affinities with $P$. rickyi n.sp. because of the low bathymetric distribution similar to that of $P$. rickyi, but they have only rough morphological affinities with this latter species. 


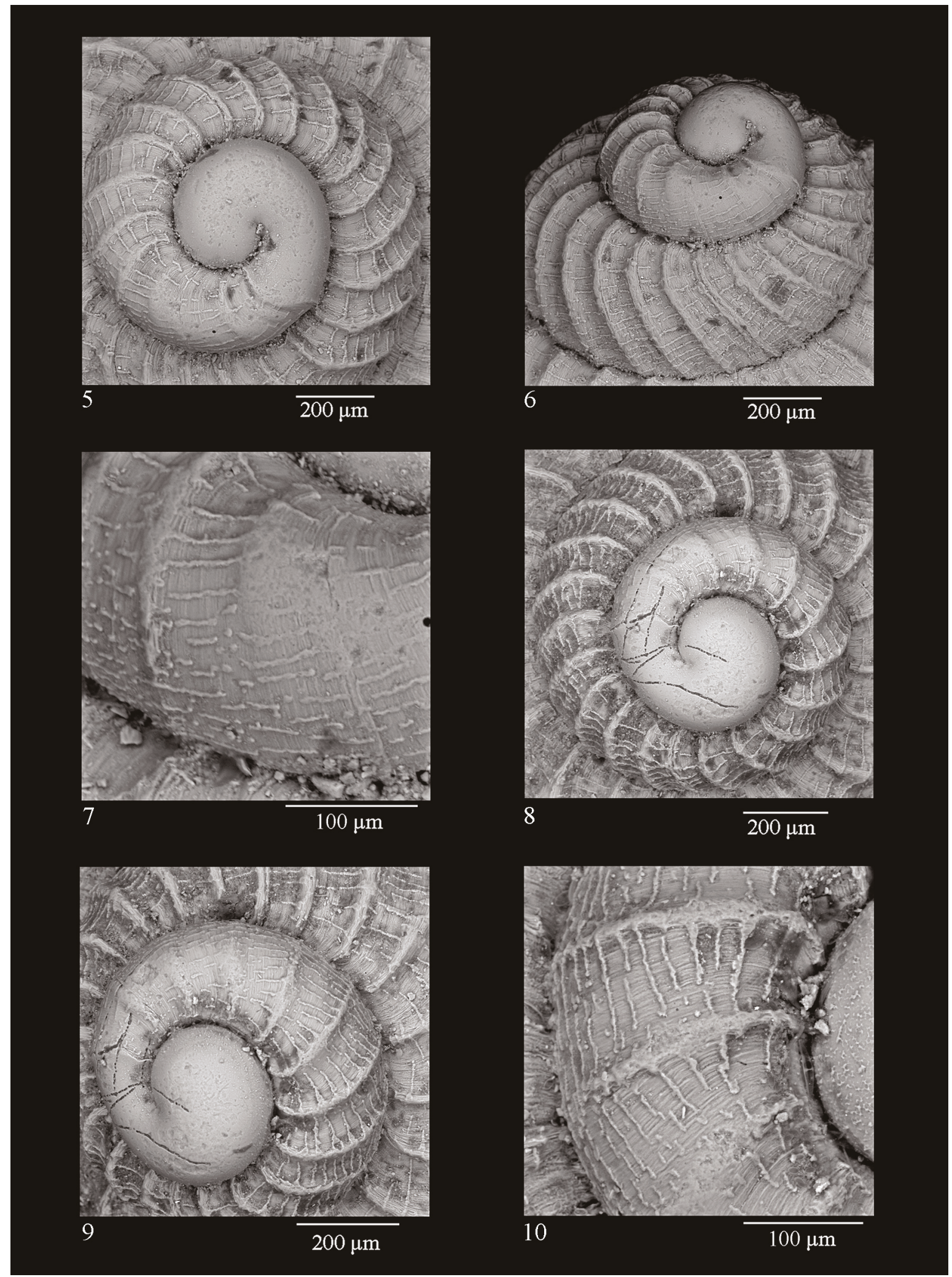

Figures 5-10. Putzeysia rickyi $\mathrm{n}$. sp. Figs. 5-7: protoconch ot the holotype and teleoconch details (MSCN 4853). Figs. 8-10, protoconch ot the paratype A and teleoconch detail (CS). 
Differences between the holotype of $P$. rickyi $\mathrm{n}$. sp. and the two Macaronesian species are here summarized in Table 1.

As could be argued by Table $1, P$. rickyi $\mathrm{n}$. sp. differs from P. franziskae and P. juttae for the more rounded shell, the larger protoconch and because the two last species have the same $\mathrm{H} / \mathrm{LW}$ ratio. Sculpture of the whorls is different. The disjoint extra-Mediterranean distribution of the last three taxa, in any case, justifies the separation at a specific level.

Putzeysia cillisi Segers, Swinnen et De Prins, 2009, only known from Madeira, is not comparable with any of the species mentioned so far, because it is more similar to the fossil species P. clathrata (Aradas, 1847) (Fig. 14) described from Gravitelli (Messina) (Guidastri et al., 1984; Segers et al., 2009) and reported only for a few Pleistocene bathyal sections of Sicily and Calabria (Aradas, 1847, Seguenza 1876a; Micali et al., 1985; Vazzana, 1996). P. rickyi n. sp. has apparently similarities with Trochus (Zizyphinus) profugus De Gregorio, 1889, considered by Monterosato (1914) and Guidastri et al. (1984), a synonym of Danilia horrida (Da Costa O.G., $1861)=$ Danilia otaviana $($ Cantraine $)=$ Danilia tinei (Calcara, 1839), but only the examination of original material labelled by De Gregorio could confirm these assessments. Libassi (1859) reports the presence of T. crispulus from the Pleistocene of Monte Pellegrino (Monterosato, 1872; 1877). The description he gives of his records, together with the reported assemblage of molluscs and their paleobathymetry, suggests instead that not $P$. wiseri, but another species is involved: probably it is not a full grown specimen of Danilia tinei (Calcara, 1839) (Monterosato, 1881) or something related to it. Aradas \& Benoit (1870) report the finding of T. crispulus along the sandy coast of Trapani; the fact that this latter could be the same species described by Philippi seems more than unlikely.

Finally, another taxon should be debated: the description of Margarites cancellata ionica by F. Nordsieck (1973) from the abyssal Ionian Sea is attributed to young specimens and fragments of adult shells of $P$. wiseri by Vatova (1974) and cannot be compared with $P$. rickyi $\mathrm{n}$. sp.

\begin{tabular}{|l|c|c|c|}
\hline Species & P. rickyi n. sp. & P. franziskae & P. juttae \\
\hline Shell tickness & Thin & Solid & Solid \\
\hline Height of the shell & $4 \mathrm{~mm}$ & $3.5 \mathrm{~mm}$ & $60.00 \%$ \\
\hline Ratio H/LW & $45.00 \%$ & $60.00 \%$ & $160 \mu \mathrm{m}$ \\
\hline Protoconch nucleus & $210 \mu \mathrm{m}$ & $110 \mu \mathrm{m}$ & $270 \mu \mathrm{m}$ \\
\hline Protoconch diameter & $410 \mu \mathrm{m}$ & $290 \mu \mathrm{m}$ & 16 \\
\hline Assial ribs on the first whorl & 20 & 12 & $17-18$ \\
\hline Assial ribs on the penultimate whorl & 27 & $14-16$ & $24-26$ \\
\hline Assial ribs on the last whorl & 38 & 30 & 3 \\
\hline $\begin{array}{l}\text { Spiral cords on the penultimate whorl } \\
\text { in apertural view }\end{array}$ & 3 & 3 & 5 \\
\hline Spiral cords on the last whorl in apertural view & 5 & 5 & narrow \\
\hline Nodulous cords of the base & 5 & $5-7$ & $6-7$ \\
\hline Nodules ornamentation inside the aperture & none & none & \\
\hline Umbilicus & narrow & & \\
\hline
\end{tabular}

Table 1. Comparison of shell characters between P. rickyi n. sp. and two Macaronesian species. 


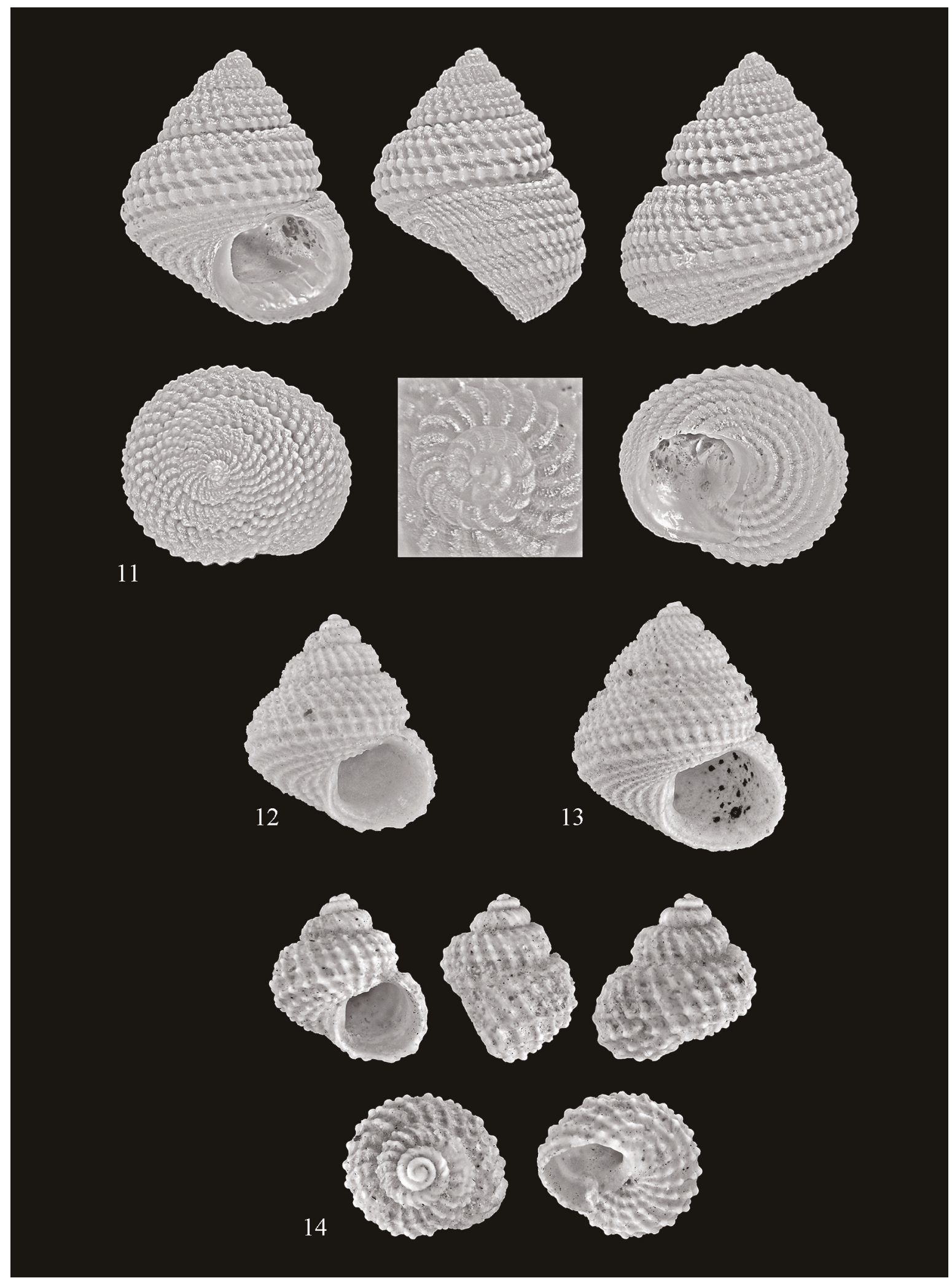

Figures 11-13. Putzeysia wiseri. Fig. 11: shell and protoconch details: height $6.5 \mathrm{~mm}$, Capraia Island, dredged at $500 \mathrm{~m}$ (NC). Fig. 12: P. wiseri shell: height 4.2 mm, Early Pleistocene of Punta Lazzi, Capo Milazzo (Messina) (CR). Fig. 13: P. wiseri shell: height $5.4 \mathrm{~mm}$, Early Pleistocene of Salice (Messina) (CR). Fig. 14: P. clathrata shell, Early Pleistocene of Salice (Messina). 
Another final note should be added to the comparison of the new species with the recently described Vetulonia giacobbei Renda \& Micali, 2016. Notwithstanding the latter is a species of Seguenzioidea, the external shell appearance could vaguely recalls that of the new species, but it is flatter and has only three teleoconch whorls, almost rounded and with a deep suture. Moreover the protoconch is bigger, almost globose, the axial ribs are weak and more numerous and a wide umbilicus is present.

\section{ACKNOWLEDGEMENTS}

The authors are grateful to Alfio Viola (University of Catania, Italy) for the assistance with the SEM acquisition of images. We also want to express our gratitude to Andrea Nappo for the loan of some digital photographs and to the Diving Sea Club, in particular Salvo Motta, Aurelio Mangano e Claudia Tomaselli (the last two, parents of Riccardo to whose memory the new species is dedicated) for logistical support during immersions. A final particular thank is due to the son of the first Author, Leonardo Reitano, for his help in preparing the equipment needed for immersions and his competence and patience in the treatment of the shell-grit and the picking of shells found.

\section{REFERENCES}

Aradas A., 1847. Descrizione delle conchiglie fossili di Gravitelli presso Messina. Atti dell'Accademia Gioenia di Scienze Naturali, ser. 2: 4: 57-58.

Aradas A. \& Benoit L., 1872-1876 (“1870”). Conchigliologia vivente marina della Sicilia e delle isole che la circondano. Atti dell'Accademia Gioenia di Scienze Naturali, ser. 3, 6: 1-113, pls 1-2 [1872]; 113-226, pls 3-4 [1874]; 227-324, pl. 5 [1876].

Ardovini R. \& Cossignani T., 1999. Atlante delle conchiglie di profondità del Mediterraneo L'Informatore Piceno Ed., Ancona. 111 pp.

Barrier P., Di Geronimo I., La Perna R., Rosso A., Sanfilippo R. \& Zibrowius H., 1996. Taphonomy of deep-sea hard and soft bottom communities: The pleistocene of Lazzaro (Southern Italy). Cominicaciòn de la II Renuniòn de Tafonomia y Fossilizaciòn, pp. 39-46.

Bertolaso L. \& Palazzi S., 2000. Note sulla raccolta Seguenza di molluschi plio-pleistocenici della Provincia di Messina presso il Museo di Geologia e Paleontologia dell'Università di Firenze. Bollettino malacologico, 35: 3-44.

Bonfitto A., Oliverio M., Sabelli B. \& Taviani M.A.,
1994. Quaternary deep-sea marine molluscan assemblage from East Sardinia (Western Tyrrhenian Sea). Bollettino malacologico, 11: 305-309.

Branca S., Coltelli M., Groppelli G. \& Lentini F., 2011. Geological map of Etna volcano, 1:50,000 scale. Italian Journal of Geosciences, 130: 265-291.

Calcara P., 1842. Nuove ricerche ed osservazioni sopra vari molluschi Siciliani. Nuove specie di Calyptrea. Il Maurolico, Giornale del Gabinetto Letterario di Messina, 13: 1-14.

Calcara P., 1845. Cenno sui molluschi viventi e fossili della Sicilia da servire da supplimento ed insieme di critiche osservazioni all'opera di R.A. Philippi. Stamperia Reale, Palermo, 65 pp., pl. 1-4.

Coan E.V. \& Kabat A.R., 2017. The malacological contributions of Rudolph Amandus Philippi (18081904). Malacologia, 60: 31-322.

Cossignani T. \& Ardovini R., 2011. Malacologia Mediterranea, Atlante delle conchiglie del Mediterraneo: 536 pp. L'informatore Piceno, Ancona.

De Gregorio A., 1889. Esame di taluni molluschi viventi e terziari del Bacino Mediterraneo. Il Naturalista siciliano, 8 (10-11): 248-256; 8 (12):275-292; pl. 4-5.

Di Geronimo I. \& Panetta P., 1973. La Malacofauna Batiale del Golfo di Taranto. Conchiglie, 9: 69-121.

Di Geronimo I., 1979. Il Pleistocene in facies batiale di Valle Palione (Grammichele, Catania). Bollettino Malacologico, 15: 85-156.

Di Geronimo I. \& Li Gioi R., 1980. La malacofauna Würmiana della Staz. BS 77/4 al largo di Capo Coda Cavallo (Sardegna Nord orientale). Annali dell'Università di Ferrara (Nuova Serie), section IX, 6 (supplement), 155-190.

Di Geronimo I. \& Bellagamba M., 1985. Malacofaune dei dragaggi BS 77-1 e BS 77-2 (Sardegna nord orientale). Bollettino della Società Paleontologica Italiana, 24: 111-129.

Di Geronimo I. \& La Perna R., 1997a. Pleistocene bathyal molluscan assemblages from Southern Italy. Rivista Italiana di Paleontologia e Stratigrafia, 103: 389-426.

Di Geronimo I., D'Atri A., La Perna R., Rosso A., Sanfilippo R. \& Violanti D., 1997b. The pleistocene bathyal section of Archi (Southern Italy). Bollettino della Società Paleontologica Italiana, 36: 189-212, 3 pls.

Di Geronimo I., Messina C., Rosso A., Sanfilippo R., Sciuto F. \& Vertino A., 2005 Enhanced biodiversity in the deep: Early Pleistocene coral communities from Southern Italy. In: Freiwald, A. \& Murray Roberts, J. (Eds), Cold-water Corals and Ecosystems, Springer, Berlin, pp. 61-86.

Engl W., 1995. Putzeysia wiseri (Archaeogastropoda, Trochidae) a common species at Lanzarote Is. (Canary Islands, Spain). Notiziario CISMA, 16: 23-26.

Giannuzzi-Savelli R., Pusateri F., Palmeri A. \& Ebreo C. 1994. Atlante delle conchiglie marine del Mediterraneo. Vol. 1 (Archaeogastropoda). La Conchiglia, Roma, 125 pp. 
Glibert M., 1962. Les Archaeogastropoda fossiles du Cénozoïque étranger des collections de l'Institut Royal des Sciences Naturelles de Belgique Institut Royal des Sciences naturelles de Belgiques, Mémoires. Deuxième série, 68: 1-131

Ghisotti F. \& Melone G.C., 1971. Catalogo illustrato delle conchiglie marine del Mediterraneo. Conchiglie, 7, supplement 3, 47-145

Guidastri R., Melone G.C. \& Taviani M., 1984. Systematic position of "Trochus" wiseri Calcara (Prosobranchia: Trochidae). Archiv fuer Molluskenkunde, 114: 125-136.

Janssen R., 1989. Benthos-Mollusken aus dem Tiefwasser des östlichen Mittelmeeres, gesammelt während der "METEOR"-Fahrt 5 (1987) // Senckenbergiana maritima. Bd.20. H.5/6. S.265-276.

Jeffreys J.G., 1880. The deep-sea Mollusca of the bay of Biscay. Annals and Magazine of Natural History, 5: 315-319.

Jeffreys J.G., 1883. On the Mollusca procured during the "Lightning" and "Porcupine" expeditions 1868-70. (Part VI). Proceedings of the Zoological Society of London. 1882: 88-115, pl. 19, 20.

Libassi I., 1859. Memoria sopra alcune conchiglie fossili dei dintorni di Palermo. Atti dell'Accademia di Scienze, Lettere e Arti di Palermo, N.S., 3: $1-47+1$ $\mathrm{pl}$

Locard A., 1898. Expéditions scientifiques du "Travailleur" et du "Talisman" pendant les années 880, 1881, 1882, 1883. Mollusques testacés. Masson, Paris, Vol. 2, 515 pp.

Marshall B., 2020 http://www.marinespecies.org/aphia.php?p=taxdetails\&id=138596; last view 27/09/2021

Marshall B., 2021. https://www.marinespecies.org/aphia.php?p=taxdetails\&id=1023120, last view 07/10/2021

Mastrototaro F., D’Onghia G., Corriero G., Matarrese A., Maiorano P., Panetta P., Gherardi M., Longo C., Rosso A., Sciuto F., Sanfilippo R., Gravili C., Boero F., Taviani M. \& Tursi A., 2010. Biodiversity of the white coral bank off Cape Santa Maria di Leuca (Mediterranean Sea): An update. Deep-Sea Research II, 57, 412-430.

Micali P. \& Villari A., 1989. Il deposito fossilifero di Salice (Messina) con particolare riguardo alle specie istituite da Giuseppe Seguenza (Contributo I). Bollettino malacologico, 25: 77-84.

Monterosato T.A., 1872. Notizie intorno alle conchiglie fossili di Monte Pellegrino e Ficarazzi. Tipografia Amenta, Palermo, $44 \mathrm{pp}$

Monterosato T.A., 1877. Catalogo delle conchiglie fossili di Monte Pellegrino e Ficarazzi presso Palermo. Bollettino R. Comitato Geologico Italiano, 8/12: 28-42.

Monterosato T.A., 1881. Nota sopra alcune conchiglie coralligene del Mediterraneo. Bullettino della Società Malacologica Italiana 6 (15-18): 243-259.

Monterosato T.A., 1914. Sur le genre Danilia. Journal de Conchyliologie, 61: 381-384; pl. IX.
Nasto I., Cardone F., Mastrototaro F., Panetta P., Rosso A., Sanfilippo R., Taviani M. \& Tursi A., 2018. Benthic invertebrates associated with subfossil coldwater coral frames and hardgrounds in the Albanian deep waters (Adriatic Sea). Turkish Journal of Zoology, 42: 360-371.

Negri M.P. \& Corselli C., 2016. Bathyal Mollusca from the cold-water coral biotope of Santa Maria di Leuca (Apulian margin, southern Italy). Zootaxa, 4186 (1): $1-97$.

Nordsieck F., 1973. Molluschi abissali dello Jonio (II parte). La Conchiglia, 5 (57-58): 4-7.

Palazzi S. \& Villari A., 1996. Malacofaune batiali pliopleistoceniche del Messinese. 2: Capo Milazzo. Il Naturalista siciliano, 20: 237-279.

Pérès J.M. \& Picard J., 1964. Nouveau manuel de bionomie benthique de la mer Méditerranée. Recueil des Travaux de la Station Marine d'Endoume, Faculté des Sciences de Marseille, 31: 1-137.

Philippi R.A., 1844. Enumeratio Molluscorum Siciliae cum viventium tum in tellure tertiaria fossilium, quae in itinere suo observavit. Volumen secundum continens addenda et emendanda, nec non comparationemfaunae recentis Siciliae cum faunis aliarum terrarumet com fauna periodi tertiariae. Eduard Anton, Halle [Halis Saxorum]. Iv+303: 13-28.

Poppe G.T. \& Goto Y., 1991. European Seashells. Volume I. (Polyplacophora, Caudofoveata, Solenogastra, Gastropoda). Verlag Christa Hemmen, Wiesbaden, $352 \mathrm{pp}$

Portalatina M., 2008. Dati sulla malacofauna marina del Salento Ionico (Puglia). Parte 1. Archeogastropoda. Bollettino malacologico, 44: 145-161.

Ratmeyer V., Beck T., Belling R., Bergenthal M., Beuck L., Brakel C., Buhmann S., Dodds L., Dorschel B., Engemann G., Foubert A., Gault J., Grehan A., Hayn C., Jurkiw A., Kahl G., Kaiser J., Klar S., Lutz M., Noe S., Papstein H., Rüggeberg A., Ruhland G., Schewe F., Schmidt W., Schröder, M., Seiter C., Truscheit T. \& Wienberg C., 2004. Cruise Report METEOR-Berichte 06-2, Cruise No. 61, Leg 3, June 4 to June 21, 2004, Cork-Ponta Delgada. Development of Carbonate Mounds on the Celtic Continental Margin, pp. 3/1-3/47.

Renda W. \& Micali P., 2016. Vetulonia giacobbei n. sp. from south Tyrrhenian Sea (Gastropoda, Seguenzioidea). Bollettino malacologico, 52: 56-59.

Rindone V. \& Vazzana A., 1989. Alcune specie di molluschi delle argille batiali del piano siciliano (Pleistocene inf.) della cava di Archi (Reggio Calabria). Bollettino malacologico, 25: 233-240.

Rosso A., Vertino A., Di Geronimo I., Sanfilippo R., Sciuto F., Di Geronimo R., Violanti D., Corselli C., Taviani M., Mastrototaro F. \& Tursi A., 2010. Hardand soft-bottom thanatofacies from the Santa Maria di Leuca deep-water coral province, Mediterranean. Deep-Sea Research II, 57: 360-379.

Scaperrotta M., Bartolini S. \& Bogi C., 2010. Accrescimenti. Stadi di Accrescimento dei Molluschi Marini 
del Mediterraneo. Vol. II. L'Informatore Piceno, 176 pp.

Segers W., Swinnen F. \& De Prins R., 2009. Marine Molluscs of Madeira. Snoeck Publishers, Heule, Belgium, 612 pp., pp. 76-77, pl. 8 fig. 2-2a.

Seguenza G., 1876a. Studii stratigrafici sulla formazione pliocenica dell'Italia meridionale (partim). Bullettino del R. Comitato Geologico d'Italia, (1-2): 8-15; (34): 92-103; (5-6): 180-189;

(7-8): 260-271; (9-10): 356-359.

Seguenza G., 1876b. Di alcuni molluschi del mare di Messina. Bullettino della Società malacologica Italiana, 2: 62-65.

Sysoev A.V., 2014. Deep-sea fauna of European seas: An annotated species check-list of benthic invertebrates living deeper than $2000 \mathrm{~m}$ in the seas bordering Europe. Gastropoda. Invertebrate Zoology, 11: 134-155.

Smriglio C., Mariottini F. \& Gravina F., 1989. Molluschi del Mar Tirreno centrale: ritrovamento di Putzeysia wiseri (Calcara, 1842), Ischnochiton vanbellei Kaas, 1985 e Neopilina zografi (Dautzenberg \& Fischer, 1896). Contributo VI. Bollettino malacologico, 25: 125-132.

Sulliotti R., 1889. Comunicazioni malacologiche. Bullettino della Società malacologica Italiana, 14: 2544.
Taviani M., Vertino A., Lopez Correa M., Savini A., De Mol B., Remia A., Montagna P., Angeletti L., Zibrowius H., Alves T., Salomidi M., Ritt B. \& Henry P. 2011. Pleistocene to Recent scleractinian deep-water corals and coral facies in the Eastern Mediterranean. Facies, 57: 579-603.

Taviani M., Angeletti L., Ceregato A., Foglini F., Froglia C. \& Trincardi F., 2013. The Gela Basin pockmark field in the strait of Sicily (Mediterranean Sea): chemosymbiotic faunal and carbonate signatures of postglacial to modern cold seepage. Biogeosciences Discussions, 10: 967-1009.

Taviani M., Angeletti L, Canese S., Cannas R., Cardone F., Cau A., Cau A.B., Follesa M.C., Marchese F., Montagna P. \& Tessarolo C., 2017. The "Sardinian cold-water coral province" in the context of the Mediterranean coral ecosystems. Deep Sea Res. Part II. Topical Studies in Oceanography, 145: 6178.

Vatova A., 1974. Sui molluschi di alcuni saggi di fondo prelevati alle soglie del mar Jonio. Conchiglie, Milano, 10: 93-112.

Vazzana A., 1996. Malacofauna batiale del Pleistocene inferiore del Vallone Catrica (Reggio Calabria, Italia). Bollettino malacologico, 31 (1995): 143-162. 